\title{
Study of the Correlation between clozapine levels and clinical findings in acutely intoxicated patients admitted to Poison Control Center-Ain Shams University Hospitals: 6 months (A prospective Study)
}

\author{
Nada Amgad Ibrahim, Mohy Kadri EL-Masry, Ayman Mohamed Abd El-Fatah ${ }^{1}$ \\ ${ }^{1}$ Department of Forensic Medicine and Clinical Toxicology, Faculty of Medicine-Ain Shams University, Cairo Egypt.
}

\begin{abstract}
Background: Clozapine (CLZ) superior efficacy compared to other antipsychotics is well established. Unlike other antipsychotic medications, a safe therapeutic blood level range for clozapine has not been clearly established.

Objective: This study was undertaken as a trial to evaluate the potential correlation between clinical findings and CLZ blood levels in patients with acute CLZ toxicity.

Methodology: A prospective study was conducted on all patients of both sexes with history of acute clozapine overdose, admitted to Poison Control Center of Ain Shams University Hospitals (PCC-ASUH) from the first of March 2019 to the end of August 2019. The total number of acutely intoxicated clozapine cases in this study was 25 patients, number admitted in 6 months period. The data collected for each patient included socio-demographic data, clinical data (intoxication data and clinical examination), laboratory investigation (including blood clozapine level), ECG, treatment, and outcome.

Results: The results showed that there was no statistically significant correlation between the blood level of clozapine and any of the studied parameters, except with the level of consciousness, where there was statistically significant increase in the level of clozapine in comatose patients compared to conscious ones.

Conclusion: It was concluded that the study suggests that there could be a potential benefit of blood clozapine level as a predictor and prognostic marker of coma in acute clozapine overdose.

Received in original form: 30 Augest 2021 Accepted in a final form: 30 October 2021

Key words Clozapine, antipsychotic, blood level, acute poisoning
\end{abstract}

\section{Introduction}

Olozapine (CLZ) has a superior efficacy compared to other antipsychotics is well established (Oyewumi et al., 2002; Sandson et al., 2007; Couchman et al., 2010). Although it is possible to measure plasma levels of other antipsychotics, CLZ is the only antipsychotic where routine monitoring of levels is not routinely available (Couchman et al., 2010; Flanagan et al., 2005).

The clinical findings like agranulocytosis and ECG changes correlation with CLZ metabolite level has been suggested as it has been found that $\mathrm{N}$ desmethylclozapine, the major CLZ metabolite, might be the cause of agranulocytosis because it is more toxic to WBC precursors than CLZ itself. Nonetheless, the CLZ plasma level associated with toxicity remains unclear (Cormac et al., 2010).

Higher CLZ levels (> $600 \mathrm{mcg} / \mathrm{L}$ ) or doses (> $600 \mathrm{mg} /$ day) and faster rate of upward titration are associated with increased risk of seizure activity. Higher CLZ levels may also be associated with hypersalivation, tachycardia, QTc prolongation, myocarditis, and cardiomyopathy (Greenwood-Smith et al., 2003; Couchman et al., 2010).

Plasma CLZ levels above $2000 \mathrm{mcg} / \mathrm{L}$ were reported to be usually associated with acute toxicity. However, there have been reports of patients with CLZ levels over $3000 \mathrm{mcg} / \mathrm{L}$ with no evidence of associated toxicity (Flanagan et al., 2005), because of these conflicting reports, this study was undertaken as a trial to evaluate the potential correlation between clinical findings and CLZ blood levels in patients with acute CLZ toxicity.

\section{Patients and Methods}

This was a prospective study that was conducted at the Poison Control Centre, Ain Shams University Hospitals (PCC-ASUH) for six months from the first of March to the end of August 2019.

Study Population

With the approval of the Ethical Committee Ain Shams University, this study included 25 patients of both sexes and different age groups (14-36) presenting with history of acute CLZ toxicity, after an informed consent was taken from each patient or their guardian. 
Inclusion Criteria: Patients of both sex and different age groups presenting with acute clozapine toxicity to Poison Control Center of Ain Shams University Hospitals with history of acute clozapine toxicity.

Exclusion Criteria: Patients with history of mixed ingestion, including co-ingestion of other antipsychotic or CNS acting drugs.

\section{Methodology}

The following data were collected:

1. Sociodemographic data: Age and gender

2. Intoxication data: Amount of ingested CLZ, mode of poisoning, time delay, and pre-consultation management.

3. Past history

a. Duration of CLZ treatment in case of previous ingestion of CLZ in both therapeutic and toxic doses.

b. Psychiatric illness including history of drug dependence.

4. Clinical data on admission

a. General examination

i. Vital data: Body temperature, heart rate, and blood pressure.

ii. Pupil size

iii. Skin changes

b. Neurologic status

i. Level of consciousness using Reed's classification of coma

ii. Autonomic dysfunction signs

iii. Extrapyramidal manifestations

5. Investigations

a. Laboratory: Blood and urine samples were withdrawn on admission and immediately tested for:

i. Arterial blood gases (ABG)

ii. Complete Blood Count (CBC)

iii. Kidney function profile: Serum urea and creatinine

iv. Urine samples were analyzed for drugs of abuse testing: Opiates, tramadol, cannabinoids, and benzodiazepines (BDZ). Remaining serum (1-1.5ml) was kept refrigerated until GC analysis was undertaken for clozapine blood level:

1. Three-mL venous blood samples were withdrawn from each patient 12 hours after ingestion and daily thereafter. After complete clotting, samples were centrifuged, and 1 to $1.5 \mathrm{~mL}$ serum were saved for CLZ blood assay.

2. CLZ level was measured by Gas Chromatography:

The therapeutic reference range of CLZ is 250 to $350 \mathrm{mcg} / \mathrm{L}(17-51$ $\mu \mathrm{mol} / \mathrm{L})^{8}$.

b. ECG: A twelve-lead ECG was done on admission and then repeated twice a day for as long as patient stayed in hospital; to assess PR interval, QRS width, QTc, and arrhythmias

\section{Statistical analysis}

A. Descriptive statistics: These were made to quantitatively describe the main features of collected data, including frequencies, percentages, maximum, minimum, means, and standard deviations.

B. Inferential statistics: Mann-Whitney test: was used to compare between two groups with quantitative data non-parametric distribution. Kruskall-Wallis test: was used to compare between more than two independent groups with quantitative data nonparametric distribution. Spearman correlation coefficients: were used to assess the correlation between two quantitative parameters in the same group.

\section{Results}

This study enrolled 25 patients, average age of whom was 24.6 years, ranging from 14-36 years. Fifty six percentages $(56 \%)$ of whom were females (Table $1)$.

All studied patients had no previous history of CLZ treatment. All studied patients exposed to toxicity through ingesting tablets in 2 concentrations: $25 \& 100$ $\mathrm{mg}$. Most of patients ingested the higher-concentration $100 \mathrm{mg}$ tablets $(64 \%)$, with average number of 8.5 tablets per patient. The resulting median total dose was $500 \mathrm{mg}$ per patient with a median delay of 4 hours between exposure and emergency room (ER) presentation. Of all studied cases, only one patient received pre-hospital treatment with flumazenil (Table 2).

Table 3 shows that $20 \%$ of studied patients had history of previous psychiatric illness. All patients were vitally stable with no skin changes. Pupils were constricted in $24 \%$ of cases, pinpoint observed in one case $(4 \%)$, and normal in the remaining cases. As regards to neurological manifestations, coma was the predominant one, being present in $92 \%$ of cases, followed by slurred speech in 2 cases $(8 \%)$, then ataxic gate, hallucination, and drowsiness by one patient showing each.

Regarding lab findings (Table 4), only 2 patients came positive in drug screening, 1 for tramadol and the other for opiates. Kidney function tests (urea and creatinine) were normal for all cases. CLZ blood level ranged from $0-80 \mu \mathrm{g} / \mathrm{ml}$ with a median of $0.65 \mu \mathrm{g} / \mathrm{ml}(650$ $\mathrm{mcg} / \mathrm{L})$. None of the studied patient had changes in TLC in their CBC tests. Only $12 \%$ of patients developed respiratory acidosis compared to 1 case (4\%) developed metabolic acidosis.

Table 5 shows that average heart rate was $93 \mathrm{bpm}$ with a range of 70-124 bpm. Rhythm was regular in all cases and $40.7 \%$ of patients developed prolonged QTc interval.

Tables 6 to 10 show that there was no statistically significant correlation between blood CLZ level and any of the studied parameters, except with coma, where CLZ blood levels were significantly higher in comatose patients compared to non-comatose ones (Table 8). 
Table (1): Distribution of patients regarding age and gender among the studied patients

\begin{tabular}{|c|c|c|c|}
\hline \multicolumn{2}{|c|}{ Age (years) (No.= 25) } & \multicolumn{2}{c|}{ Gender (No.= 25) } \\
\hline Mean \pm SD & Range & Female & $11(44.0 \%)$ \\
\hline $24.56 \pm 6.27$ & $14-36$ & $14(56.0 \%)$ & Male \\
\hline
\end{tabular}

SD standard deviation

Table (2): Distribution of intoxication data among the studied patients.

\begin{tabular}{|l|l|l|}
\hline \multicolumn{1}{|c|}{ Parameter } & \multicolumn{1}{c|}{ Findings (No.= 25) } \\
\hline \multirow{2}{*}{ CLZ tablet concentration (mg) } & $25 \mathrm{mg}$ & $9(36.0 \%)$ \\
\cline { 2 - 3 } Number of Tablets & $100 \mathrm{mg}$ & $16(64.0 \%)$ \\
\hline \multirow{2}{*}{ Total dose } & Mean \pm SD & $8.52 \pm 4.80$ \\
\cline { 2 - 3 } & Range & $2-20$ \\
\hline Route of intoxication & Median (Inter Quartile Range) & $500(250-1000)$ \\
\cline { 2 - 3 } Delay (Hours) & Range & $50-2000$ \\
\hline Previous CLZ treatment & Oral & $25(100.00 \%)$ \\
\hline \multirow{2}{*}{ Prehospital treatment } & Median (IQR) & $4(3-7)$ \\
\cline { 2 - 3 } & Range & $1-24$ \\
\hline \multirow{2}{*}{ SD stand } & $25(100.00 \%)$ \\
\hline
\end{tabular}

SD standard deviation

Table (3): Distribution of history and physical finding among the studied patients.

\begin{tabular}{|l|l|l|}
\hline \multicolumn{1}{|c|}{ Parameter } & \multicolumn{2}{c|}{ Findings (No.= 25) } \\
\hline Psychiatric illness & No & $20(80.00 \%)$ \\
\cline { 2 - 3 } & Yes & $5(20.00 \%)$ \\
\hline Vital data & Stable & $25(100.00 \%)$ \\
\hline \multirow{5}{*}{ Pupil } & Normal Equal Reactive & $18(72.00 \%)$ \\
\cline { 2 - 3 } & Constricted Equal Reactive & $6(24.00 \%)$ \\
\cline { 2 - 3 } & Pinpointed Equal & $1(4.00 \%)$ \\
\hline Skin changes & No & $25(100.00 \%)$ \\
\hline \multirow{5}{*}{ Neurological manifestations } & Coma & $23(92.00 \%)$ \\
\cline { 2 - 3 } & Slurred speech & $2(8.00 \%)$ \\
\cline { 2 - 3 } & Ataxic gait & $1(4.00 \%)$ \\
\cline { 2 - 3 } & Hallucination & $1(4.00 \%)$ \\
\cline { 2 - 3 } & Drowsy & $1(4.00 \%)$ \\
\hline
\end{tabular}

\section{SD standard deviation}

Table (4): Distribution of laboratory results among the studied patients.

\begin{tabular}{|c|c|c|c|}
\hline \multicolumn{2}{|c|}{ Parameter } & \multicolumn{2}{|c|}{ Findings (No.= 25) } \\
\hline \multirow[t]{4}{*}{ Drug screen } & Opiates & Positive & $1(4.0 \%)$ \\
\hline & Tramadol & Positive & $1(4.0 \%)$ \\
\hline & Cannabis & Positive & $0(0.0 \%)$ \\
\hline & BDZ & Positive & $0(0.0 \%)$ \\
\hline \multirow[t]{4}{*}{ Kidney function tests } & \multirow[t]{2}{*}{ Urea } & Mean \pm SD & $13.32 \pm 4.71$ \\
\hline & & Range & $7-24$ \\
\hline & \multirow[t]{2}{*}{ Creatinine } & Mean \pm SD & $0.76 \pm 0.20$ \\
\hline & & Range & $0.1-1.12$ \\
\hline \multirow{2}{*}{\multicolumn{2}{|c|}{ CLZ blood level (mcg/ml) }} & Median (IQR) & $0.65(0.41-1.80)$ \\
\hline & & Range & $0-80$ \\
\hline CBC & & No agranulocytosis & $25(100.0 \%)$ \\
\hline \multirow{3}{*}{\multicolumn{2}{|c|}{$\mathbf{A B G}$}} & Normal & $21(84.0 \%)$ \\
\hline & & Respiratory acidosis & $3(12.0 \%)$ \\
\hline & & Metabolic acidosis & $1(4.0 \%)$ \\
\hline
\end{tabular}


Table (5): Distribution of ECG finding among the studied patients.

\begin{tabular}{|l|l|l|}
\hline Parameter & \multicolumn{2}{|c|}{ Findings (No.= 25) } \\
\hline \multirow{2}{*}{ Rate } & Mean \pm SD & $93.48 \pm 14.50$ \\
\cline { 2 - 3 } & Range & $70-124$ \\
\hline \multirow{2}{*}{ QThythm } & Regular & $25(100.00 \%)$ \\
\cline { 2 - 3 } & Rean \pm SD & $0.47 \pm 0.09$ \\
\hline
\end{tabular}

SD standard deviation

Table (6): Mann Whitney statistical to Correlate of CLZ blood level to some studied parameters

\begin{tabular}{|l|l|l|}
\hline \multirow{2}{*}{ Parameter } & \multicolumn{2}{c|}{ Correlation with CLZ blood level $(\boldsymbol{\mu g} / \mathbf{m l})$} \\
\cline { 2 - 3 } Age & \multicolumn{1}{|c|}{ r } & \multicolumn{1}{c|}{ P-value* } \\
\hline Number of Tablets & -0.236 & 0.256 \\
\hline Total dose of CLZ (mg) & -0.100 & 0.633 \\
\hline Delay (Hours) & 0.135 & 0.520 \\
\hline Urea & -0.221 & 0.289 \\
\hline Creatinine & -0.125 & 0.552 \\
\hline Rate & 0.079 & 0.708 \\
\hline QTc & 0.289 & 0.161 \\
\hline
\end{tabular}

$* P>0.05:$ Nonsignificant $P<0.05$ : Significant $P<0.01$ : Highly significant.

Table (7): Correlation of CLZ blood level to gender, concentration, psychiatric illness, and previous consultation treatment using Mann Whitney test.

\begin{tabular}{|c|c|c|c|c|c|c|}
\hline \multirow{2}{*}{\multicolumn{2}{|c|}{ Parameter }} & \multicolumn{2}{|c|}{ CLZ blood level (ug/ml) } & \multirow{2}{*}{ Test value } & \multirow{2}{*}{ P value* } & \multirow{2}{*}{ Sig. } \\
\hline & & Median (IQR) & Range & & & \\
\hline \multirow{2}{*}{ Gender } & Female & $0.78(0.43-18.25)$ & $0.06-80.0$ & \multirow{2}{*}{$-0.986 \bullet$} & \multirow{2}{*}{0.324} & \multirow{2}{*}{ NS } \\
\hline & Male & $0.52(0.20-0.87)$ & $0.00-50.00$ & & & \\
\hline \multirow{2}{*}{ CLZ dose (mg) } & $25 \mathrm{mg}$ & $0.43(0.09-0.65)$ & $0-25.9$ & \multirow{2}{*}{-1.755} & \multirow{2}{*}{0.079} & \multirow{2}{*}{ NS } \\
\hline & $100 \mathrm{mg}$ & $0.87(0.45-10.13)$ & $0-80$ & & & \\
\hline \multirow{2}{*}{ Psychiatric illness } & No & $0.57(0.34-10.03)$ & $0.00-80.0$ & \multirow{2}{*}{$-0.034 \bullet$} & \multirow{2}{*}{0.973} & \multirow{2}{*}{ NS } \\
\hline & Yes & $0.86(0.52-0.90)$ & $0.00-2.00$ & & & \\
\hline \multirow{2}{*}{ Pre-consultation treatment } & No & $0.59(0.34-1.90)$ & $0.00-80.0$ & \multirow{2}{*}{$-0.277 \bullet$} & \multirow{2}{*}{0.781} & \multirow{2}{*}{ NS } \\
\hline & Flumazenil & $0.86(0.86-0.86)$ & $0.86-0.86$ & & & \\
\hline
\end{tabular}

$* P$-value >0.05: Non-significant (NS); P-value <0.05: Significant (S); P-value< 0.01: highly significant $(H S)$.

- Mann-Whitney test.

Table (8): Correlation of CLZ blood level to neurological manifestations.

\begin{tabular}{|c|c|c|c|c|c|c|}
\hline \multirow{2}{*}{\multicolumn{2}{|c|}{ Parameter }} & \multicolumn{2}{|c|}{ CLZ blood level (ug/ml) } & \multirow{2}{*}{ Test value } & \multirow{2}{*}{ P value* } & \multirow{2}{*}{ Sig. } \\
\hline & & \multirow{2}{*}{$\begin{array}{c}\text { Median (IQR) } \\
0.47(0.20-1.80) \\
\end{array}$} & \multirow{2}{*}{$\begin{array}{l}\text { Range } \\
0.00-80.0\end{array}$} & & & \\
\hline \multirow{3}{*}{ Pupil } & Normal Equal Reactive & & & \multirow{3}{*}{$1.312^{f}$} & \multirow{3}{*}{0.519} & \multirow{3}{*}{ NS } \\
\hline & Constricted Equal Reactive & $0.89(0.76-2.00)$ & $0.27-50.00$ & & & \\
\hline & Pinpointed Equal & $0.52(0.52-0.52)$ & $0.52-0.52$ & & & \\
\hline \multirow{2}{*}{ Coma } & No & $0.04(0.00-0.09)$ & $0.00-0.20$ & \multirow{2}{*}{$-2.054^{\circ}$} & \multirow{2}{*}{0.040} & \multirow{2}{*}{$\mathrm{S}$} \\
\hline & Yes & $0.76(0.43-2.00)$ & $0.00-80.0$ & & & \\
\hline \multirow{2}{*}{ Slurred speech } & No & $0.65(0.41-1.80)$ & $0.00-80.0$ & \multirow{2}{*}{$-0.050^{\circ}$} & \multirow{2}{*}{0.960} & \multirow{2}{*}{ NS } \\
\hline & Yes & $34.13(0.00-68.25)$ & $0.00-68.25$ & & & \\
\hline \multirow{2}{*}{ Ataxic gait } & No & $0.71(0.42-1.90)$ & $0.00-80.0$ & \multirow{2}{*}{$-1.595^{\circ}$} & \multirow{2}{*}{0.111} & \multirow{2}{*}{ NS } \\
\hline & Yes & $0.00(0.00-0.00)$ & $0.00-0.00$ & & & \\
\hline \multirow{2}{*}{ Hallucination } & No & $0.59(0.34-1.74)$ & $0.00-80.00$ & \multirow{2}{*}{$-1.664^{\circ}$} & \multirow{2}{*}{0.096} & \multirow{2}{*}{ NS } \\
\hline & Yes & $68.25(68.25-68.25)$ & $68.25-68.25$ & & & \\
\hline \multirow{2}{*}{ Drowsy } & No & $0.71(0.42-1.90)$ & $0.00-80.0$ & \multirow{2}{*}{$-1.110^{\circ}$} & \multirow{2}{*}{0.267} & \multirow{2}{*}{ NS } \\
\hline & Yes & $0.20(0.20-0.20)$ & $0.20-0.20$ & & & \\
\hline
\end{tabular}

* P-value >0.05: Nonsignificant (NS); P-value <0.05: Significant (S); P-value < 0.01: highly significant $(H S)$

- Mann Whitney test

$\neq$ Kruskal Wallis test 
Table (9): Kruskal Wallis statistical analysis to Correlate CLZ blood level to ABG findings.

\begin{tabular}{|c|c|c|c|c|c|c|}
\hline \multirow{2}{*}{\multicolumn{2}{|c|}{ Parameter }} & \multicolumn{2}{|c|}{ CLZ blood level (ug/ml) } & \multirow{2}{*}{ Test value } & \multirow{2}{*}{$P$ value* } & \multirow{2}{*}{ Sig. } \\
\hline & & Median (IQR) & Range & & & \\
\hline \multirow{3}{*}{ ABG } & Normal & $0.65(0.41-1.68)$ & $0-68.25$ & \multirow{3}{*}{0.944} & \multirow{3}{*}{0.624} & \multirow{3}{*}{ NS } \\
\hline & Respiratory acidosis & $0.52(0-80)$ & $0-80$ & & & \\
\hline & Metabolic acidosis & $2(2-2)$ & $2-2$ & & & \\
\hline
\end{tabular}

* P-value >0.05: Nonsignificant (NS); P-value <0.05: Significant (S); P-value <0.01: highly significant (HS)

Table (10): Mann Whitney statistical to Correlate CLZ blood level to drug tests and outcome.

\begin{tabular}{|c|c|c|c|c|c|c|}
\hline \multirow{2}{*}{\multicolumn{2}{|c|}{ Parameter }} & \multicolumn{2}{|c|}{ CLZ blood level (ug/ml) } & \multirow{2}{*}{ Test value } & \multirow{2}{*}{ P value* } & \multirow{2}{*}{ Sig. } \\
\hline & & Median (IQR) & Range & & & \\
\hline \multirow{2}{*}{ Opiate } & Negative & $0.71(0.34-1.9)$ & $0-80$ & \multirow{2}{*}{-0.139} & \multirow{2}{*}{0.890} & \multirow{2}{*}{ NS } \\
\hline & Positive & $0.52(0.52-0.52)$ & $0.52-0.52$ & & & \\
\hline \multirow{2}{*}{ Tramadol } & Negative & $0.71(0.34-1.9)$ & $0-80$ & \multirow{2}{*}{-0.555} & \multirow{2}{*}{0.579} & \multirow{2}{*}{ NS } \\
\hline & Positive & $0.43(0.43-0.43)$ & $0.43-0.43$ & & & \\
\hline \multirow{2}{*}{ Outcome } & Consented discharge & $0.81(0.42-1.35)$ & $0.06-80.00$ & \multirow{2}{*}{-0.435} & \multirow{2}{*}{0.663} & \multirow{2}{*}{ NS } \\
\hline & Recovery & $0.48(0.20-2.00)$ & $0.00-68.25$ & & & \\
\hline
\end{tabular}

$*$ P-value >0.05: Nonsignificant (NS); P-value <0.05: Significant (S); P-value< 0.01: highly significant (HS)

\section{Discussion}

The present study showed that there was no statistically significant correlation between the level of CLZ and genders among the studied patients, agreeing with Bowskill et al., (2010). The present generalization is that females tend to have relatively higher CLZ blood level (Castberg et al., 2017). However, this understanding is related to patients on regular CLZ treatment rather than acute overdose patients. Also, many other factorrs such as smoking, caffeine intake, co-treatment with other metabolims inducers, BMI, and inflammation may affect the clozpine blood level (Taylor et al., 2015).

This study also found no correlation between CLZ level and age. Another study found that CLZ blood concentartion was higher after age of 65 even with decreasing therapeutic dose. The current study was limited to young and middle-aged patients (14-36 y, mean $=24.6$ ) with no significant comorbidities, so results could have been different if older patents were included (Bowskill et al., 2010).

The study at hand shows that there was no statistically significant correlation between the blood level of CLZ and either number of tablets, concentration, or total dose of CLZ ingested. This could be attributed to the wide variation between patients in the rate at which they metabolize CLZ into norclozapine (50-fold). This was opposite to another study that stated that there is a definite relationship between the dose of CLZ and the plasma CLZ and norclozapine concentrations (Yusufi et al., 2007). Other previous studies have reported that the oral CLZ dose is insufficient to explain the high interindividual variability of serum levels (RostamiHodjegan et al., 2004; Lane et al., 1999).

The present study showed that there was no statistically significant correlation between the blood level of CLZ among the studied patients and the time-delay between exposure and presentation to the PCC. This is attributed to the delayed absorption due to gastrointestinal hypomobility induced by CLZ; CLZ does not follow single-compartment model of metabolism; in addition to the previously mentioned different factors affecting its metabolism (Fang et al., 2014). In our study, the time interval between CLZ consumption and blood level testing has been variable and may have contributed to the lack of correlation.

In the current study, there was no statistically significant correlation between the level of CLZ among the psychiatric patients and non-psychiatric patients. Higher serum CLZ levels have been reported to be associated with greater cognitive impairment in patients with chronic schizophrenia after adjusting for the effects of age, sex, and oral dose (Adler et al., 2002; Rajji et al., 2010). Again, great interpersonal variability exit depending on the previously mentioned factors and may considerably change the plasma levels. Regarding the neurological manifestations, there was statistically significant increase in the level of CLZ in comatose patients compared to conscious patients. The clear indications for the therapeutic drug monitoring (TDM) of CLZ are signs of central nervous system toxicity, which can be linked to serum level. Most sources suggest levels greater than $600 \mathrm{mcg} / \mathrm{L}$ related to serious side effects. The risk of developing seizures appears to increase with higher concentrations $(>1000$ mcg/L) (Zernig et al., 2007).

There was no statistically significant correlation between CLZ level and ECG rate, rhythm, or the prolongation of QTc interval. A retrospective study enrolled patients with acute psychotropic drug overdose showed that QTc prolongation occurred in $40.5 \%$ of patients (Miura et al., 2015), similar to the results of our study. The potential mechanism underlying QTc prolongation of antipsychotic drugs is based on their ability to block the rapidly activating delayed rectifier potassium current (IKr), which leads to lengthening of cardiac repolarization (Kim et al., 2018). Absence of correlation could be explained considering that QTc prolongation is determined not only by the medication, but also by other patient's risk factors, which include old age, female sex, congenital long QT syndrome, heart conditions, electrolyte abnormalities, and concurrent use of medications that 
prolong the QT interval or inhibit the metabolism of a drug that prolongs the QT interval (Leung et al., 2012). The current study shows no statistically significant correlation between CLZ level and ABG changes among studied patients. In a previous study, authors showed that psychotropic medications, especially CLZ, were the most common cause of poisoning associated with mixed respiratory alkalosis and metabolic acidosis (Hamdi et al., 2016). Metabolic disturbances associated with CLZ treatment could related to its ability to bind wide range of receptors including muscarinic and adrenergic receptors, leading to potential autonomic dysfunctions (Yuen et al., 2018). The reported respiratory acidosis in the current study can be explained by impaired ventilation following central nervous system depression. Myocardial impairment/hypotension results in reduced tissue perfusion and the production of lactate leading to metabolic acidosis.

The study at hand shows no correlation between the plasma level of CLZ among the studied patients and drug screening of tramadol, cannabis, opiate, or benzodiazepine. Comorbid substance use disorder is common in patients with schizophrenia (Regier et al., 1990) and is associated with a variety of serious adverse consequences such as hospitalization (Swofford et al., 1996). Several reports suggest that CLZ may have the effect of decreasing the use of alcohol or/and other drugs of abuse among patients with schizophrenia (Drake et al., 2000). However, several investigators have in fact argued that abuse of alcohol and other drugs may worsen adherence to antipsychotic pharmacotherapy, including CLZ (Werner and covenas, 2017). Based on this, the findings of the current study were not unexpected considering that only $20 \%$ patients gave history of previous psychiatric illness, $4 \%$ were positive in drug screening, and none have history of previous CLZ treatment.

The present study detected no statistically significant correlation between the level of CLZ among the studied patients and their mean urea and creatinine values. Acute interstitial nephritis (AIN) is a rare, but potentially fatal, adverse reaction to CLZ (Hunter et al., 2009). Acute renal failure due to neuroleptic malignant syndrome is well known as well (Strawn et al., 2007). The relatively small number and low severity of the studied cases in the present study may explain why such result was reached.

Since $100 \%$ of patients enrolled in the present study had full recovery, we found no statistically significant correlation between CLZ level and the outcome. This came in agreement with Paksu et al. (2014) who found that the majority of patients with psychotropics toxicity recover well with supportive therapy. Similarly, Elhady et al., (2016) pointed that acute overdose with antipsychotics seldom results in death. Again, the relatively small number and low severity of the studied cases in the present study may explain why such result was reached.

\section{Conclusion}

The current study concluded that there was statistically significant increase in the level of CLZ in comatose patients compared to conscious ones. This suggests that the potential benefit of blood CLZ level as a predictor of coma in acute CLZ overdose needs to be assessed.

\section{References}

Adler G, Grieshaber S, Faude V, Thebaldi B, Dressing H, (2002): Clozapine in patients with chronic schizophrenia: serum level, EEG and memory performance. Pharmacopsychiatry, 35(05):190194.

Bowskill S, Couchman L, MacCa J, (2012): Plasma clozapine and norclozapine in relation to prescribed dose and other factors in patients aged 65 years and over: data from a therapeutic drug monitoring service, 1996-2010. Hum Psychopharmacol Clin Exp, 27:277-283.

Castberg I, Westin AA, Skogvoll E, Spigset O. Effects of age and gender on the serum levels of clozapine, olanzapine, risperidone, and quetiapine. Acta Psychiatr Scand. 2017 Nov;136(5):455-464. doi: 10.1111/acps.12794

Cormac I, Brown A, Creasey S, Ferriter M, Huckstep B, (2010): A retrospective evaluation of the impact of total smoking cessation on psychiatric inpatients taking clozapine. Acta Psychiatr Scand, 121(5):393-397. doi:10.1111/j.16000447.2009.01482.x

Couchman L, Morgan PE, Spencer EP, Flanagan RJ, (2010): Plasma clozapine, norclozapine, and the clozapine:norclozapine ratio in relation to prescribed dose and other factors: data from a therapeutic drug monitoring service, 1993-2007. Ther Drug Monit, 32(4):438-447. doi:10.1097/FTD.0b013e3181dad1fb

Drake RE, Xie H, McHugo GJ, Green AI, (2000): The effects of clozapine on alcohol and drug use disorders among patients with schizophrenia. Schizophr Bull, 26(2):441-449. doi:10.1093/oxfordjournals.schbul.a033464

El-Hady Hammad S, Girgis N, Zaher Amin S, Zanaty A, El-Kawy Abou Hatab H, (2016): Evaluation of acute antipsychotic poisoned cases. Menoufia Med J, 29(4):1116-1121. doi:10.4103/11102098.202527

Fang J, Mosier K. (2014). Literature values of terminal half-lives of clozapine are dependent on the time of the last data point. Journal of Pharmacy \& Pharmaceutical Sciences;17(2):187- 189.

Flanagan RJ, Spencer EP, Morgan PE, Barnes TRE, Dunk L, (2005): Suspected clozapine poisoning in the UK/Eire, 1992-2003. Forensic Sci Int., 155(2-3):91-99. doi:10.1016/j.forsciint.2004.10.024

Greenwood-Smith C, Lubman DI, Castle DJ, (2003): Serum clozapine levels: a review of their clinical utility. J Psychopharmacol Oxf Engl.,17(2):234-238. doi:10.1177/0269881103017002014

Hamdi H, Hassanian-Moghaddam H, Hamdi A, Zahed NS, (2016): Acid-base disturbances in acute poisoning and their association with survival. $\mathbf{J}$ Crit Care., 35:84-89. doi:10.1016/j.jcrc.2016.05.003 
Hunter R, Gaughan T, Queirazza F, McMillan D, Shankie S, (2009): Clozapine-induced interstitial nephritis - a rare but important complication: a case report. J Med Case Rep., 3:8574.

Kim DD, White RF, Barr AM, Honer WG, Procyshyn RM, (2018): Clozapine, elevated heart rate and QTc prolongation. J Psychiatry Neurosci JPN., 43(1):71-72. doi:10.1503/jpn.170135

Lane HY, Chang YC, Chang WH, Lin SK, Tseng YT, Jann MW, (1999): Effects of gender and age on plasma levels of clozapine and its metabolites: Analyzed by critical statistics. J Clin Psychiatry., 60(1):36-40.

Leung JYT, Barr AM, Procyshyn RM, Honer WG, Pang CCY, (2012): Cardiovascular side-effects of antipsychotic drugs: the role of the autonomic nervous system. Pharmacol Ther., 135(2):113122. doi:10.1016/j.pharmthera.2012.04.003

Miura N, Saito T, Taira T, Umebachi R, Inokuchi S,(2015): Risk factors for QT prolongation associated with acute psychotropic drug overdose. Am J Emerg Med., 33(2):142-149. doi:10.1016/j.ajem.2014.09-048

Oyewumi LK, Cernovsky ZZ, Freeman DJ, Streiner DL, (2002): Relation of blood counts during clozapine treatment to serum concentrations of clozapine and nor-clozapine. Can J Psychiatry Rev Can Psychiatr., 47(3):257-261. doi:10.1177/070674370204700306

Paksu S, Duran L, Altuntas M, Zengin H, Salis O, Ozsevik SN, Albayrak H, Murat N, Guzel A, Paksu MS. (2014). Amitriptyline overdose in emergency department of university hospital: Evaluation of 250 patients. Human \& experimental toxicology. 33(9):980-90.

Rajji TK, Uchida H, Ismail Z, Ng W, Mamo DC, Remington G, Pollock BG, Mulsant BH. (2010). Clozapine and global cognition in schizophrenia. Journal of clinical psychopharmacology. 30(4):431-6.

Regier DA, Farmer ME, Rae DS, Locke BZ, Keith SJ, Judd LL, Goodwin FK. (1990). Comorbidity of mental disorders with alcohol and other drug abuse: results from the Epidemiologic Catchment Area (ECA) study. Jama. 264(19):2511-8.
Rostami-Hodjegan A, Amin AM, Spencer EP, Lennard M. Influence of dose, cigarette smoking, age, sex, and metabolic activity on plasma clozapine concentrations: a predictive model and nomograms to aid clozapine dose adjustment and to assess compliance in individual patients. J Clin Psychopharmacol. 2004;24(1):70-78.

Sandson NB, Cozza KL, Armstrong SC, Eckermann G, Fischer BA, Phillips B., (2007): Clozapine case series. Psychosomatics., 48(2):170-175. doi:10.1176/appi.psy.48.2.170

Strawn JR, Keck PE, Caroff SN, (2007): Neuroleptic malignant syndrome. Am J Psychiatry.,164(6):870-876. doi:10.1176/ajp.2007.164.6.870

Swofford CD, Kasckow JW, Scheller-Gilkey G, Inderbitzin LB, (1996): Substance use: a powerful predictor of relapse in schizophrenia. Schizophr Res., 20(1-2):145-151. doi:10.1016/0920-9964(95)00068-2

Taylor D, Paton C, Kapur S. The Maudsley, (2015): Prescribing Guidelines in Psychiatry. 12th ed. Wiley Blackwell; 109-112.

Werner F-M, Covenas R, (2017) Long-term Administration of Antipsychotic Drugs in Schizophrenia and Influence of Substance and Drug Abuse on the Disease Outcome. Curr Drug Abuse Rev.,10(1):19-24. doi:10.2174/1874473710666171020104524

Yuen JWY, Kim DD, Procyshyn RM, White RF, Honer WG, Barr AM, (2018): ClozapineInduced Cardiovascular Side Effects and Autonomic Dysfunction: A Systematic Review. Front Neurosci, 12:203. doi:10.3389/fnins.2018.00203

Yusufi B, Mukherjee S, Flanagan R, Paton C, Dunn G, (2007): Prevalence and nature of side effects during clozapine maintenance treatment and the relationship with clozapine dose and plasma concentration. Int Clin Psychopharmacol, 22(4):238-243.

Zernig G, Ng K, Hiemke C, Saria A, (2007): Therapeutic drug monitoring-based clozapine dosing recommendations. Ther Drug Monit, 29(1):130-131. doi:10.1097/FTD.0b013e31802c052e 


\section{دراسة الارتباط بين مستوى الكلوزابين و النتائج السريرية في حالات التسمم الحاد للمرضى المحجوزين

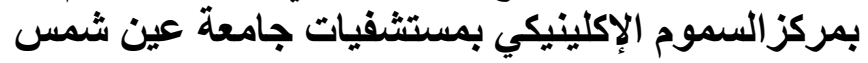

$$
\begin{aligned}
& \text { 'ندى أبحد إبراهيم وحي قدري المصري و أمن عمد عبد الفتاح' } \\
& \text { الملخص العربي }
\end{aligned}
$$

المقدمة:

إن فعالية عقار الكلوز ابين أمر لا شك فيه،بخلاف بقية أدوية مضادات الذهان لم يحدد بوضوح مجال أمن للجر عات العلاجية للكلوز ابين, وما يز ال مستوى الكلوز ابين المصاحب للسميّة مبهمًا.

الهدف من الاراسة :

وإنما تهدف هذه الدراسة لتقصي الارتباط بين التظاهرات السريرية ومستويات الكلوزابين في الدم لدى مرضى التسمم الحاد بالكلوزابين، لتقدير أهمية مستويات الكلوز ابين في تقييم شدة التسمح.

منهجية الدراسة:

وقد أجريت دراسة وصفية مستقلية على كل مرضى التسمم الحاد من كلوزابين من كلا الجنسين والذين قد أدخلوامركز علاج التسمم

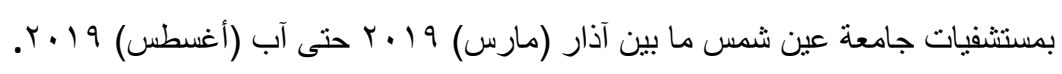

بلغ إجمالي عدد حالات التسمم الحاد بالكلوز ابين في هذه الدراسة م مريضًا أدخلوا على فترة ستة أشهر. تم تحصيل بيانات العمر و الجنس و البيانات السريرية و المختبرية بما فيها مستوى الكلوز ابين بالدم و وتغيرات رسم القلب الكهربائي و العلاج و النتيجة لكل منهم.

نتائج الدراسة :

ما من زيادة ذات دلالة إحصائية تذكر بين مسنوى الكلوزابين لاى المرضى محل الدراسة وبين البيانات المدروسة ما عدى في المرضى

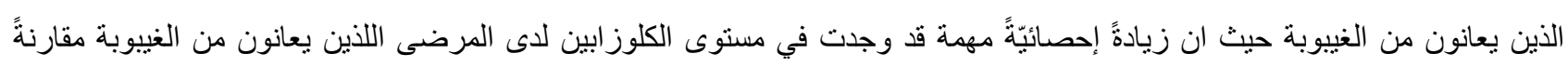
بالو اعين منهم. الخلاصة : وقد استنتج من الدراسة انه من المرجح وجود فائدة من قياس مستوى الكلوز ابين بالدم لتوقع نتائج مرضي الغيبوبة في حالات التسمم الحاد بالكلوز ابين. 